\title{
Reflection on the Network Consensus under the View of Journalism and Communication
}

\author{
Mao Qian \\ Zhengzhou University of Light Industry, Zhengzhou, Henan, China \\ 603959781@qq.com
}

Keywords: journalism and communication; network consensus; information technology

\begin{abstract}
The extensive application of information technology gradually expands the new media team based on the internet and occupies the large market. It is the revolutionary change in the field of journalism and communication. In this paper, the author analyzed the reflection on network consensus under the view of journalism and communication.
\end{abstract}

\section{Introduction}

The extensive application of information technology gradually expands the new media team based on the internet and occupies the large market. It is the revolutionary change in the field of journalism and communication. Lots of media join in news reports. Meanwhile, bad news is constantly expanding, resulting in the serious negative influences. How to carry out management and guide in consensus is the urgent problem to be solved by journalists in today's society.

\section{Development and Guide of Network Consensus under the View of Journalism and Communication}

\subsection{Mode of consensus guide}

In January 2017, Xinhuanet consensus monitoring center issued the Consensus Report of Social Hotspot Network 2016. By sorting out and summarizing hotspot consensus events in 2016, the author indicated that over 2/3 hotspot public opinions are developed from We-media under the historical background of big data. The specific data are shown in Figure 1.

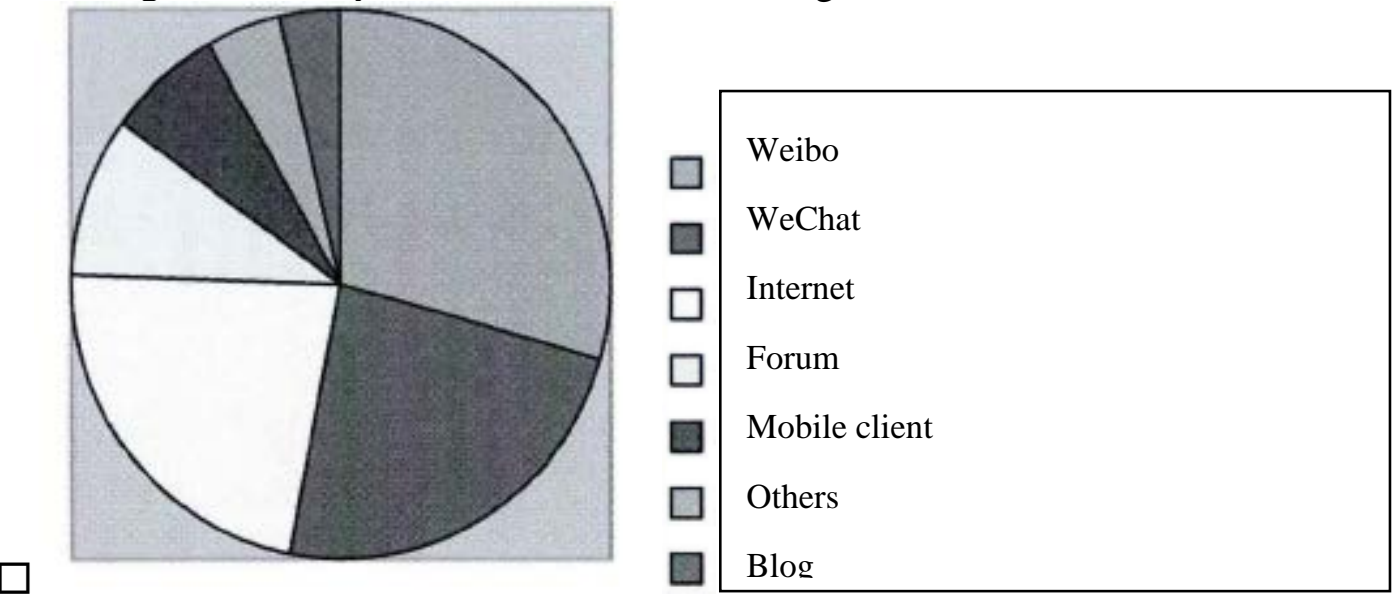

Fig.1 Communication Platform Publication of Social Hotspot Public Opinions

With the constant updating of the network spread platform, the network mobilization capacity is increasingly enhancing. The network consensus events and close association between the governmental work and social governance propose a new challenge for the government to guide the network consensus, including gov.cn governmental website, governmental affairs APP, 
governmental affairs weibo, governmental affair WeChat official account, and governmental headline. The internet governmental affair platform has already become the important platform for governmental institutions to issue authorized information and respond to the public concern.

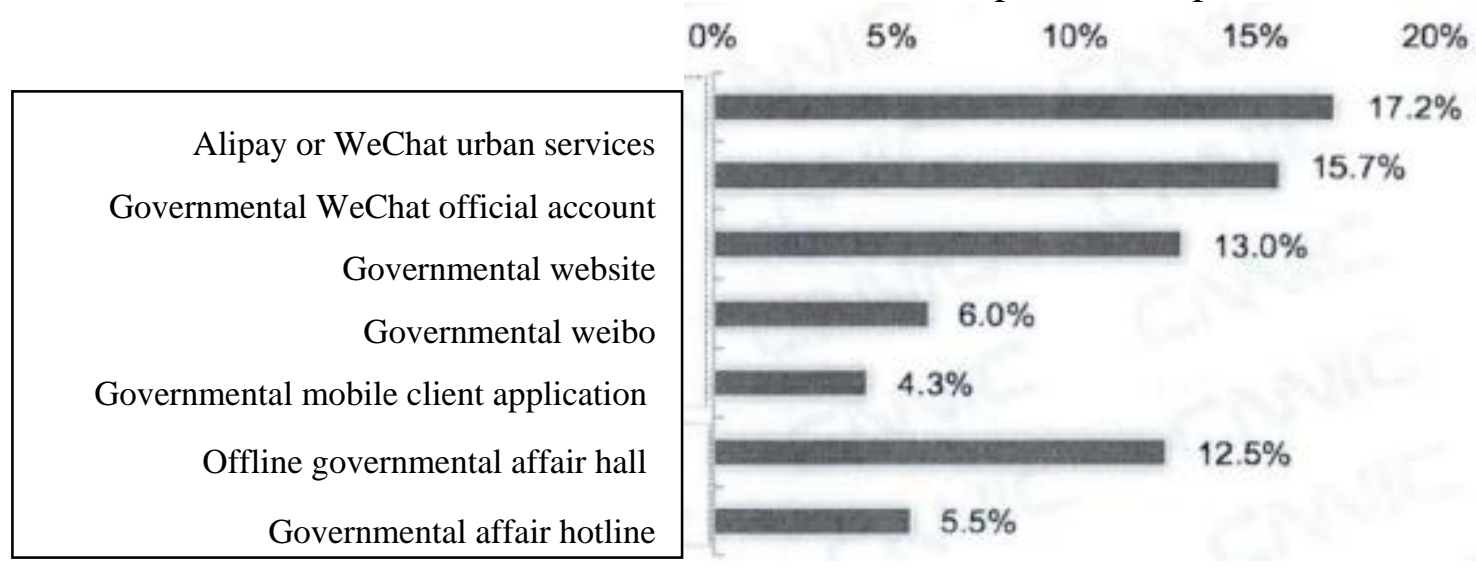

Fig.2. User Usage Rate of Various Governmental Affair Services for Netizens in 2016

\subsection{Steps of consensus guide}

The first step of consensus guide is to rapidly identify the event topic of threatening organizational development. In event identification, it is necessary to notice event property and staging features of network consensus in disaster emergencies by staging Shenzhen Landslide Event on "December 20"(see Table 1), so as to redisplay the event consensus changing process and guide practice of the local government in this event consensus intuitively. Shenzhen Guangming New District Industrial Park took place the landslide event at 11:40 on December 20, 2015.

The period from December 20, 2015 to December 25, 2015 was treated as the outbreak period in this event, including gold $72 \mathrm{~h}$ of rescue after landslide and rescue miracle possibility exceeding expectation. Within the 72h after taking place the geological disaster, the survival rate of victims is present in the negative correlation with time. It can be observed from Table 2 that in top 5 days after taking place the event, media reports and netizen searching highly focused on the topic of disaster rescue situation and maintained the follow-up state.

To sum up, network consensus triggered by “12.20” Shenzhen landslide event was present in the continuously increasing popularity and interacting with the positive and negative opinions. Official governmental affair Weibo and WeChat official account, as well as weibo and WeChat and client of traditional media occupy the dominant status in this event. We-media undoubtedly fully embodies the supervision role of the governmental actions, so as to make public opinions become the "benchmarking” of relevant measures' effect in emergencies and "wind indicator" of public intentions.

\section{The Strategy of Purifying the Network Consensus under the View of Journalism and Communication}

\subsection{Media should intensify their responsibilities}

Facing to the severe network consensus situation, media, as the primary media of information communication, should complete their own duties, change the part that doesn't conform to the development of era, optimize organizational framework, actively integrate with new media, expand the mode of information publication, and use authorized opinions to support themselves, so as to effectively control public opinion direction and enhance attraction to audiences.

\subsection{Perfect relevant management and supervision mechanism}

In terms of the news media, it is necessary to constantly update the concept of journalism and communication. In the new historical period, journalism communication has the new contents and 
presentation modes. Workers should constantly learn and comprehend it and accept the cutting-edge knowledge to comprehend the network consensus. The management department should construct and perfect the relevant management mechanism, confirm the strict management regulations for reference, and purify the network consensus environment.

Table 1 News Search Correlation Quantity on “12.20” Shenzhen Landslide Event

\begin{tabular}{|c|c|c|c|}
\hline Date & Title & Websites & 158 items \\
\hline Dec.21 & $\begin{array}{c}\text { Investigation on Shenzhen landslide: } 16 \text { relatives and } \\
\text { friends of a man lost contact }\end{array}$ & Tencent & 65 items related \\
\hline Dec.22 & $\begin{array}{l}\text { Ministry of Land and Resources investigated the } \\
\text { causes for Shenzhen landslide }\end{array}$ & $21 \mathrm{CN}$ & 128 items related \\
\hline Dec.23 & $\begin{array}{l}2 \text { survivors were found out in Shenzhen landslide } \\
\text { field: one person was sober and one person was } \\
\text { insensible }\end{array}$ & Sohu & 55 items related \\
\hline Dec.24 & $\begin{array}{c}\text { The overall recording of rescuing the first survivor in } \\
\text { Shenzhen landslide }\end{array}$ & Netease & 112 items related \\
\hline Dec. 25 & 75 people in Shenzhen landslide lost contact. & Xinhuanet & 5 items related \\
\hline Dec.26 & $\begin{array}{l}\text { Shenzhen landslide was determined as the production } \\
\text { safety accident }\end{array}$ & Beijing Times & 4 items related \\
\hline Dec.27 & $\begin{array}{c}\text { Causes for Shenzhen landslide accident were } \\
\text { investigated thoroughly to look into liabilities } \\
\text { seriously }\end{array}$ & Xinhuanet & 9 items related \\
\hline Dec.28 & $\begin{array}{l}1 \text { million cashes were rescued from Shenzhen } \\
\text { landslide and it was returned to the origin owner }\end{array}$ & Netease & 6 items related \\
\hline Jan.6 & $\begin{array}{l}77 \text { people lost contact in Shenzhen landslide accident. } \\
58 \text { people were victims. }\end{array}$ & Xinhuanet & 1 item related \\
\hline Jan.7 & 77 people lost contact in Shenzhen landslide accident. & PhoenixNet & 10 item related \\
\hline Jan.9 & $\begin{array}{c}5 \text { people in Shenzhen landslide were arrested and } \\
\text { determined as crime of negligently causing a serious } \\
\text { accident }\end{array}$ & $\begin{array}{l}\text { Nanfang } \\
\text { Network }\end{array}$ & 1 item related \\
\hline Jan.13 & 69 victims were found out in Shenzhen X11 landslide & Xinhuanet & 158 items \\
\hline Jan.15 & $\begin{array}{c}\text { Relevant person in charge in Shenzhen landslide was } \\
\text { arrested by police }\end{array}$ & Xinhuanet & 65 items related \\
\hline Jan.16 & $\begin{array}{c}3 \text { suspects of Shenzhen landslide accident were } \\
\text { rewarded for arrest }\end{array}$ & $\begin{array}{l}\text { Beiqing } \\
\text { Network }\end{array}$ & 128 items related \\
\hline Jan.18 & $\begin{array}{l}12 \text { suspects with malfeasance crimes involved in } \\
\text { Shenzhen landslide event were placed on file and } \\
\text { investigated. }\end{array}$ & PhoenixNet & 55 items related \\
\hline Jan.23 & $\begin{array}{l}\text { Dafa Zhenqian gambling: one suspect in Shenzhen } \\
\text { landslide event has surrendered. }\end{array}$ & $\begin{array}{l}\text { Xiaoxiang } \\
\text { Morning } \\
\text { News }\end{array}$ & 112 items related \\
\hline Jan.24 & $\begin{array}{c}3 \text { escaped suspects in Shenzhen landslide event were } \\
\text { present court }\end{array}$ & Sina & 5 items related \\
\hline Jan.26 & $\begin{array}{l}\text { Guangdong Two Sessions mentioned that illegal } \\
\text { buildings are the cancer in Shenzhen landslide }\end{array}$ & Xinhuanet & 4 items related \\
\hline Jan.28 & $\begin{array}{l}42 \text { suspects in Shenzhen landslide event were present } \\
\text { court and signed a compensation agreement. }\end{array}$ & PhoenixNet & 9 items related \\
\hline Feb.2 & $\begin{array}{l}\text { Rescue task of Shenzhen landslide was completed } \\
\text { successfully. }\end{array}$ & $\begin{array}{l}\text { Guangming } \\
\text { Network }\end{array}$ & 6 items related \\
\hline Jul.16 & Shenzhen event investigation report was published. & Netease & 1 item related \\
\hline Jul.18 & $\begin{array}{l}110 \text { people in charge were disposed in } 12.20 \\
\text { Shenzhen landslide event. }\end{array}$ & $\begin{array}{l}\text { Guangming } \\
\text { Network }\end{array}$ & 10 items related \\
\hline
\end{tabular}


Table 2 Information Issued by Governmental News

\begin{tabular}{|c|c|c|c|}
\hline Session & Publication time & Spokesmen & Publication contents \\
\hline 1 & Dec.20, 2015, 17:15 & $\begin{array}{l}\text { The deputy secretary general of the municipal } \\
\text { government-Li Yikang }\end{array}$ & $\begin{array}{l}\text { Accident condition and } \\
\text { rescue work arrangement }\end{array}$ \\
\hline 2 & Dec.20, 2015, 23:30 & $\begin{array}{l}\text { The emergency office director in } \\
\text { Shenzhen-Yang Feng }\end{array}$ & $\begin{array}{l}\text { Basic information and } \\
\text { rescue work situation }\end{array}$ \\
\hline 3 & Dec.21, 2015, 09:00 & Deputy mayor in Shenzhen—Liu Qingsheng & $\begin{array}{l}\text { Rescue work of latest } \\
\text { disaster situation }\end{array}$ \\
\hline 4 & Dec.21, 2015, 14:30 & $\begin{array}{l}\text { Director in Shenzhen Ministry of Housing and } \\
\text { Urban-rural Development-Yang Shengjun } \\
\text { and researcher in Chinese railway Academy of } \\
\text { Science-Liu Guonan }\end{array}$ & $\begin{array}{lr}\text { Professional } & \text { rescue } \\
\text { measures and } & \text { rescue } \\
\text { difficulty analysis } & \end{array}$ \\
\hline 5 & Dec.22, 2015, 15:00 & $\begin{array}{l}\text { Deputy mayor in Shenzhen-Liu Qingsheng, } \\
\text { director } n \text { Shenzhen Ministry of Housing and } \\
\text { Urban-rural Development-Yang Shengjun } \\
\text { and director in Guangming New District } \\
\text { Management Committee-Kuang Bing }\end{array}$ & Latest rescue process \\
\hline 6 & Dec.23, 2015, 07:00 & $\begin{array}{l}\text { Deputy director in Shenzhen emergency } \\
\text { center-Zhou Qiang, the director in } \\
\text { neurosurgery department of Shenzhen No.2 } \\
\text { People's Hospital-Wang Yiguo, Dr. Dai } \\
\text { Limeng in neurosurgery in Shenzhen People’s } \\
\text { Hospital, commander in armed police } \\
\text { hydropower headquarters-Major General } \\
\text { Yue Xi, division chief of public security fire } \\
\text { control crops in Guangdong-Gao Cunyi and } \\
\text { chief fire officer-Wang Guoshe }\end{array}$ & $\begin{array}{l}\text { Patient situation of rescue } \\
\text { and answered journalists' } \\
\text { questions }\end{array}$ \\
\hline 7 & Dec.23, 2015, 17:30 & $\begin{array}{l}\text { Member of standing committee and executive } \\
\text { vice mayor in Shenzhen-Zhang Hu }\end{array}$ & $\begin{array}{l}\text { Placement situation of } \\
\text { disaster victims, next work } \\
\text { arrangement and answered } \\
\text { journalists' questions }\end{array}$ \\
\hline 8 & Dec.24, & $\begin{array}{l}\text { Deputy secretary general in Shenzhen } \\
\text { Government-Zhu Yanfeng, director in } \\
\text { Shenzhen Population and Family Planning } \\
\text { Commission-Luo Lexuan, the leader in } \\
\text { national, provincial, and municipal associated } \\
\text { expert medical group-Shi Guangzhi, deputy } \\
\text { supervisor in medical expert group and expert } \\
\text { in traumatic orthopedics, South Hospital of } \\
\text { Southern Medical University-Professor Lin } \\
\text { Angru, deputy director in Shenzhen Center for } \\
\text { Disease Control-Professor Ma Hanwu, and } \\
\text { leader in mental crisis intervention expert } \\
\text { group of emergencies in Shenzhen-Professor } \\
\text { Liu Tiebang }\end{array}$ & $\begin{array}{l}\text { Rehabilitation placement, } \\
\text { focused on introducing the } \\
\text { latest estimation of the } \\
\text { victim Tian Yangming, } \\
\text { disease defense of disease in } \\
\text { the field, and answered } \\
\text { journalists' questions }\end{array}$ \\
\hline 9 & Dec.25, 2015, 17:00 & $\begin{array}{l}\text { Director in Shenzhen Ministry of Housing and } \\
\text { Urban-rural Development-Yang Shengjun } \\
\text { and director in safety production } \\
\text { administration in Guangming New } \\
\text { District-Li Jiannan }\end{array}$ & $\begin{array}{l}\text { Prevention on secondary } \\
\text { disasters }\end{array}$ \\
\hline 10 & Dec.25, 2015, 20:00 & $\begin{array}{l}\text { Provincial deputy secretary in Guangdong and } \\
\text { Shenzhen municipal party secretary-Ma } \\
\text { Xingrui }\end{array}$ & $\begin{array}{l}\text { Result report identified by } \\
\text { disaster investigation group }\end{array}$ \\
\hline
\end{tabular}

\subsection{Citizens should enhance identification consciousness}

In addition to media and management department, public opinion consciousness is also of great importance. Many rumors can be spread to common people. In terms of the public people, basic 
cognition errors can be observed to enhance information identification and effectively avoid from public opinion communication of rumors and false information.

\section{Conclusions}

The network public opinions were analyzed from the perspective of journalism and communication, so as to help us to recognize public opinions. Network consensus environment has an influence on everyone. Bad network environment will constitute in the potential threats to the national and social stability. As a whole, journalism and communication can be considered as the effective means to guide us to correctly solve network public opinion problems, thus it is deserved for us to deeply discuss and study it. Moreover, it is good for us to build the harmonious and positive network public environment.

\section{References}

[1] Xiao Wentao and Huang Xuejian, the Discussion on the Unbalance Problems of Network Public Opinion Power in the Full-media Era[J], China Administration Management, 2015(08): 6-12.

[2] Ye Zhanbei, Adapting to Demassification and Differential Communication Tendency to Speed up the New Pattern in Consensus Guide - the Perspective of Network Communication [J], Jiangsu Social Science, 2016(03): 1-9.

[3] Wu Tong, the Public Management Dilemma and Countermeasures in Network News Opinions [J], Journal of Nantong University(Social Science Version), 2016, 32(04): 156-160.

[4] Zhang Zhi'an and Yan Qihong, the Conceptual Cognition, Analytical Hierarchy and Guide Strategy of Network Consensus [J], the Research on Journalism and Communication, 2016, 23(05):20-29+126.

[5] Chen Qiulei, the Guide Problem of Network Consensus-with the Perspective of Marxism News View [J], Knowledge and Action, 2017(05): 13-16. 